\title{
Adolf Martens and the Research on Martensite
}

H. Czichos, Bundesanstalt für Materialforschung und -prüfung (BAM) D-1000 Berlin 45

\section{Introduction and overview}

Adolf Martens is considered together with personallties like te Chatelier, Howe, Osmond, Roberts-Austen, Sorby. Stead and Tschernoff as one of the founders of metallography in the 19 th century (1). On occasion of the 75th anniversary of $h$ is death, a short portrayal of his $l$ ife and work is presented. In addition to the retrospect, the present state of research on martensits with respect to the basic classes of materials - metals, ceramics and polymers - as well as the study on biological martensitic transformations is illustrated in brief by some examples.

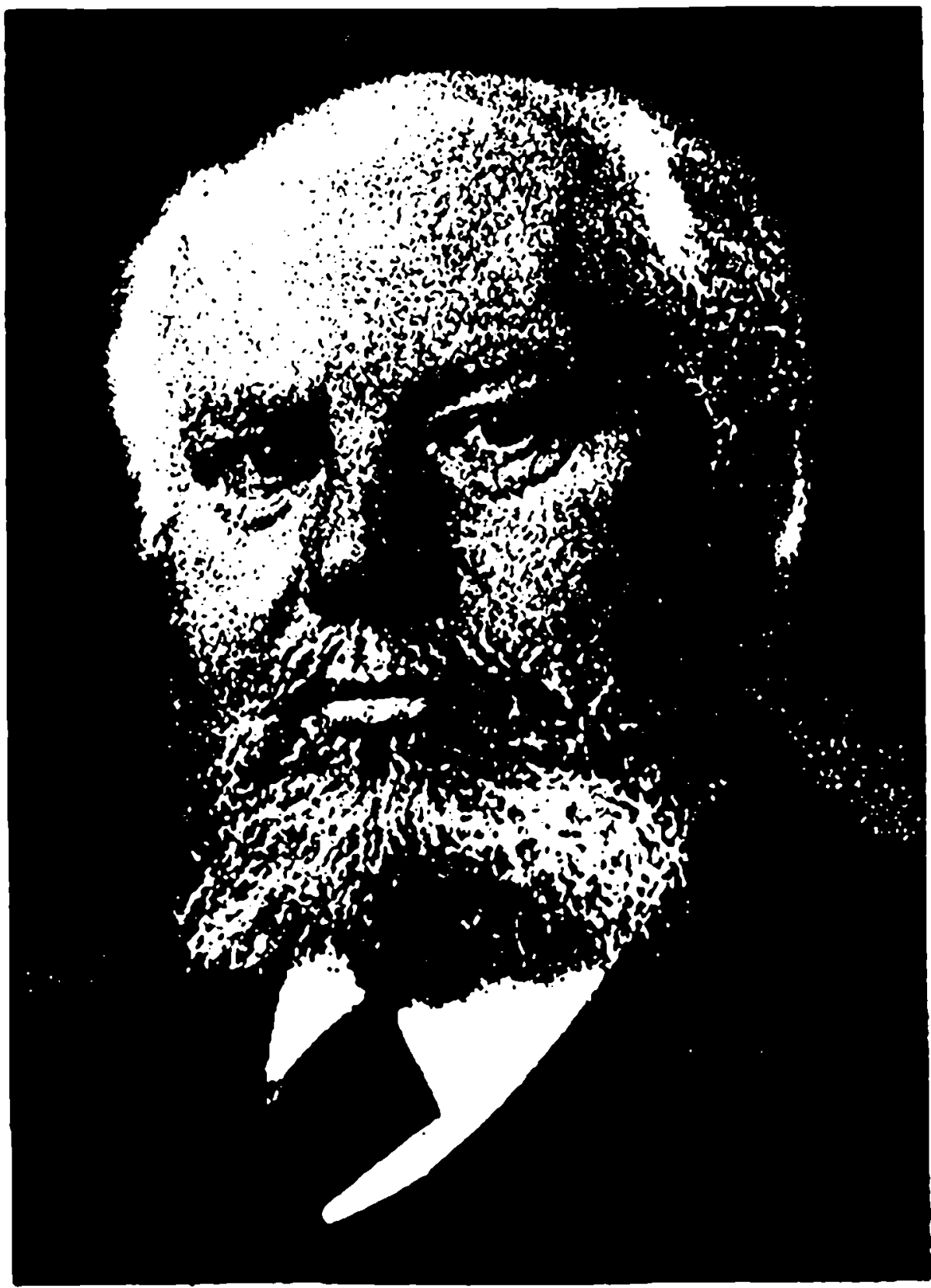

Fig. 1 : 


\section{The life of Adolf Martens}

Adolf Martens, born March 6,1850 in the district of Mecklenburg. reccived an engineering education at the Royal "Gewerbeaxademie" Bcrlin after a practicnl training at a machine factory. and joined in 1871 the enginecring staff of the Royal prussian Railways. There he worked in the fields of iron and steel structures and quality control of railway components. In 1880 he became an assistant to Professor Consentius at the Technische Hochschule (TH) Berlin-Charlottenburg and was appointed in 1884 Head of a small Mechanical-Technical Testing Institute at the TH. This institute merged with a Chemical-Technical Testing Institute and a Test office for Civil Pinginecring Materials to form in 1904 under the directorship of Adolf Martens the Royal Material Testing office - a predecessor institute of the present Federal Institute for Materials Research and Testing (BAM). Adolf Martens was appointed Professor in 1889. Member of the Royol Academy of Sciences Berlin in 1904 and received a honorary doctor's degree from the Technische Hochschule Dresden in 1905. After a life full of scientific-technological work and the successful establishment of the Royal Materials Testing office as one of the leading institutions of its kind worldwide, he died on July, 24, 1914 (2, 3).

\section{The work 으 A Adolf Martens}

Adolf Martens was a strong personality with immense working and management capabilities, extreme broad technological interest, profound englneering skills and scientific creativity. Figure 1 shows a photograph of him. In his early years, when he worked for the Royal prussian Railways, he could perform his metallographic work only in his spare time at his own expense. For his studies, he developed by himself the experimental tools he needed, including an optical microscope with a new illumination technique, see Figure $2(4)$.

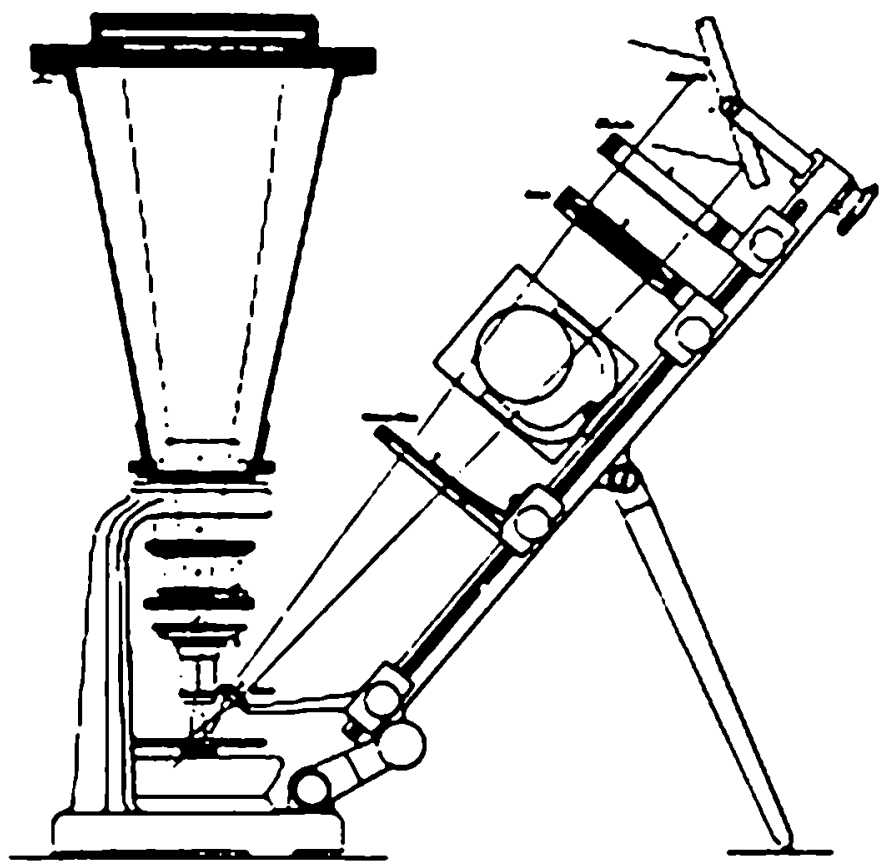

Pig. 2: Optical microscope, designed by Adoll Martens (1880) 
Rirysulalldruxr

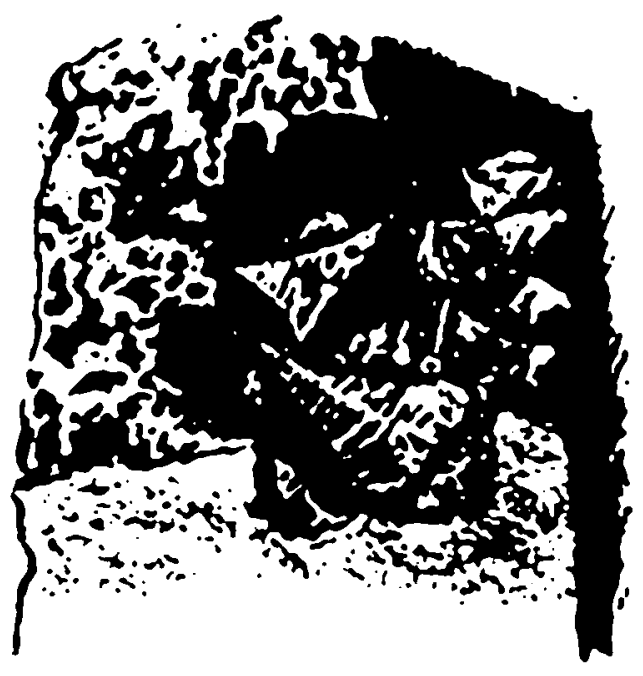

hienmuil

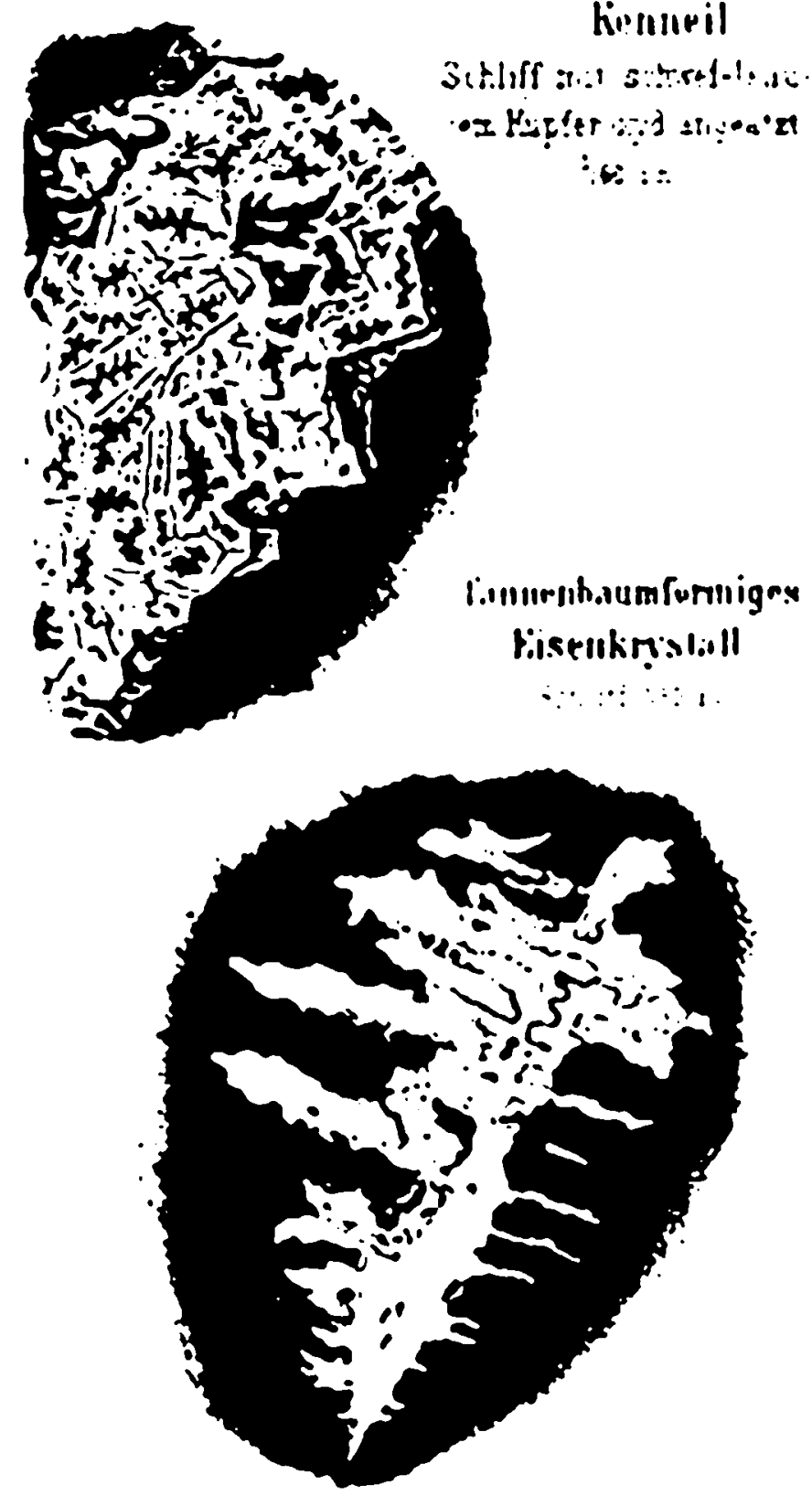

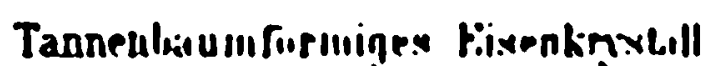

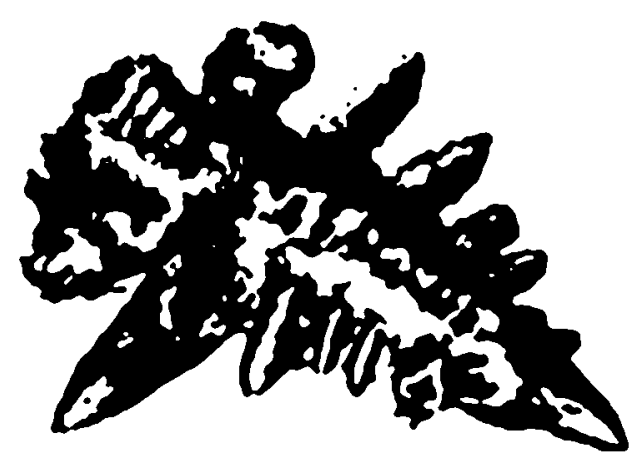

Spiegeloismin I. Rnulind shüllr

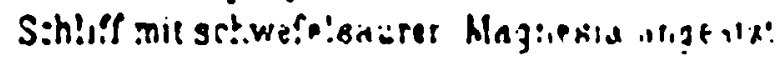
i.ass I I1

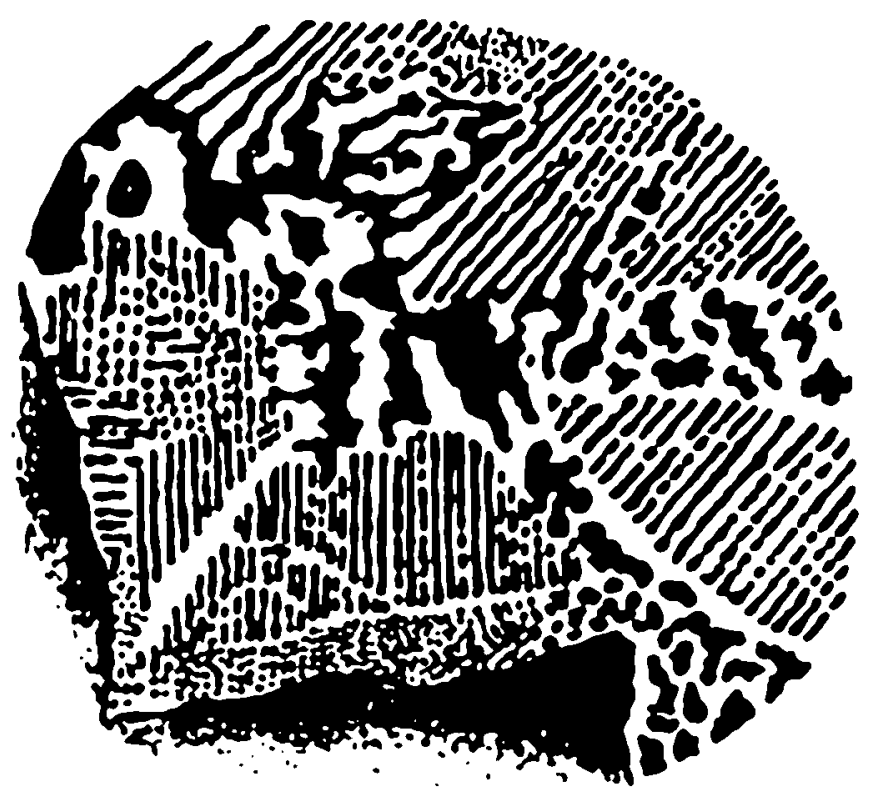

\section{Mlatrlons:}

lobre dir mikiruslingiselen

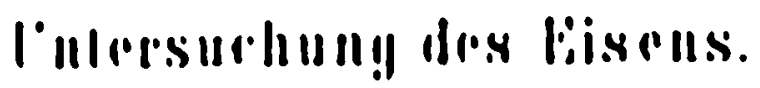

Fig.3 Microstructural investigation of Iron 
Because at this time it way very difticult to obtain microphotographs of good quality. Martens made very accurate drawings of the micrustructures with the help of a special optical prism attached to the microscope. Later, in collaboration with the Carl zelss establishment he deslgned "what was to be the best equipment for metallographir. photomicrugraphy for several decades" (1).

He studied fractured as well as polished surfaces and developed special etching techniques to visualize specific microstructural features, see figure 3. He complled the results of his studies meticulously in his technical note books. Figure 4 shows a page of his note books.

In addition to his metallographic studies and the development of the ronnected apparatus and techniques, he designed instruments and techniques for other areas of materials research and testing. for example the Martens tensile tester $(50.000 \mathrm{kgf})$, the Martens scratch hardness tester and the Martens lubricant oil test rig, just to mention a few.

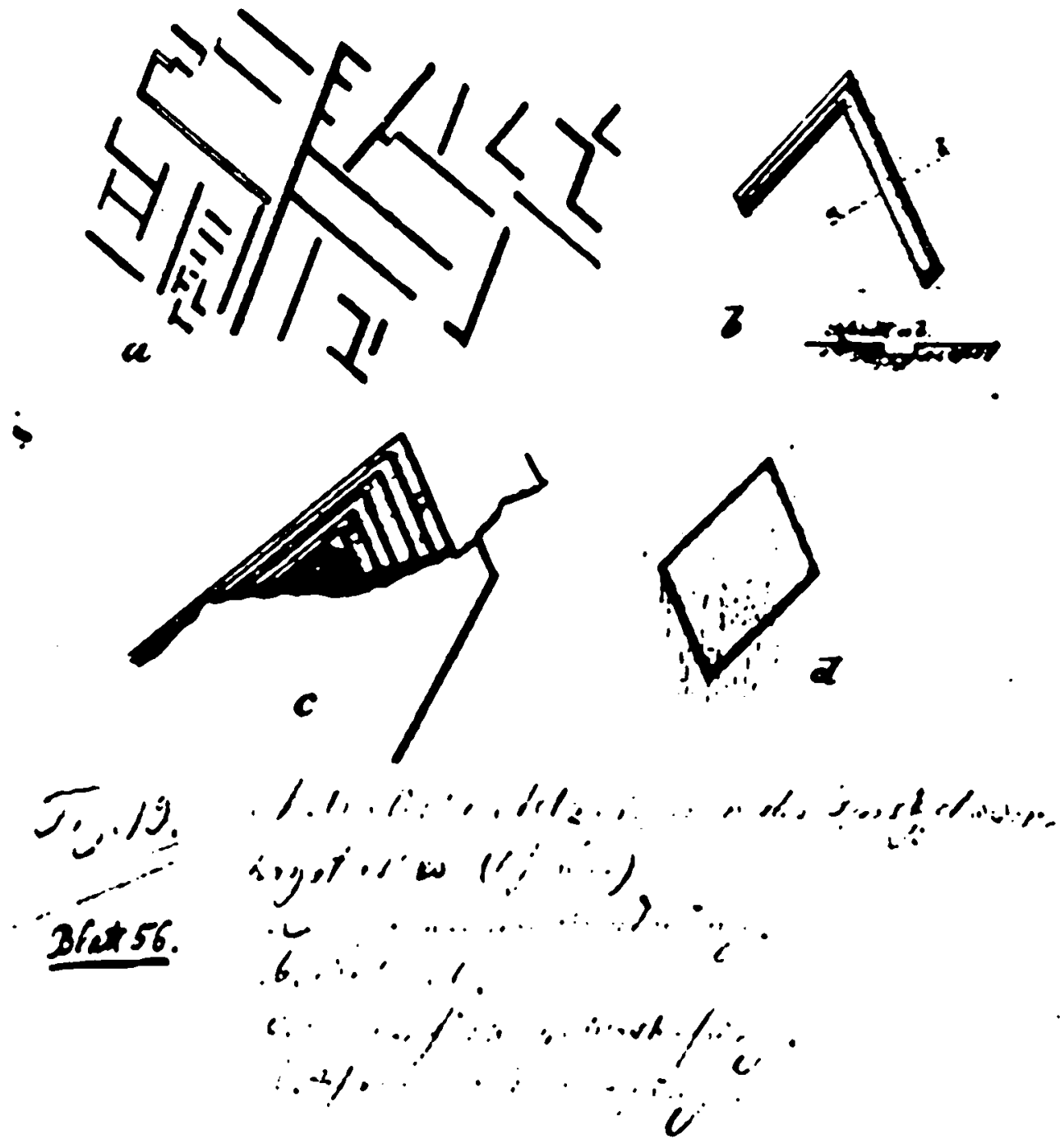

Fig. 4: Microstructure of Splegelelsen (etched details) 
The accuracy of Martens metallogrephle gtudias can be lllustratod In comparing hls drawinga (laft) with contemporary alcroqraphs (right) of materials. Imlinr to those ho otudied. This 18 shown for thn oxamples of a dendritle structure, Plg. 5, a fracture surfaco, PIg. 6, and an otchod microstructure, Flg. 7. $(5,6,7)$.
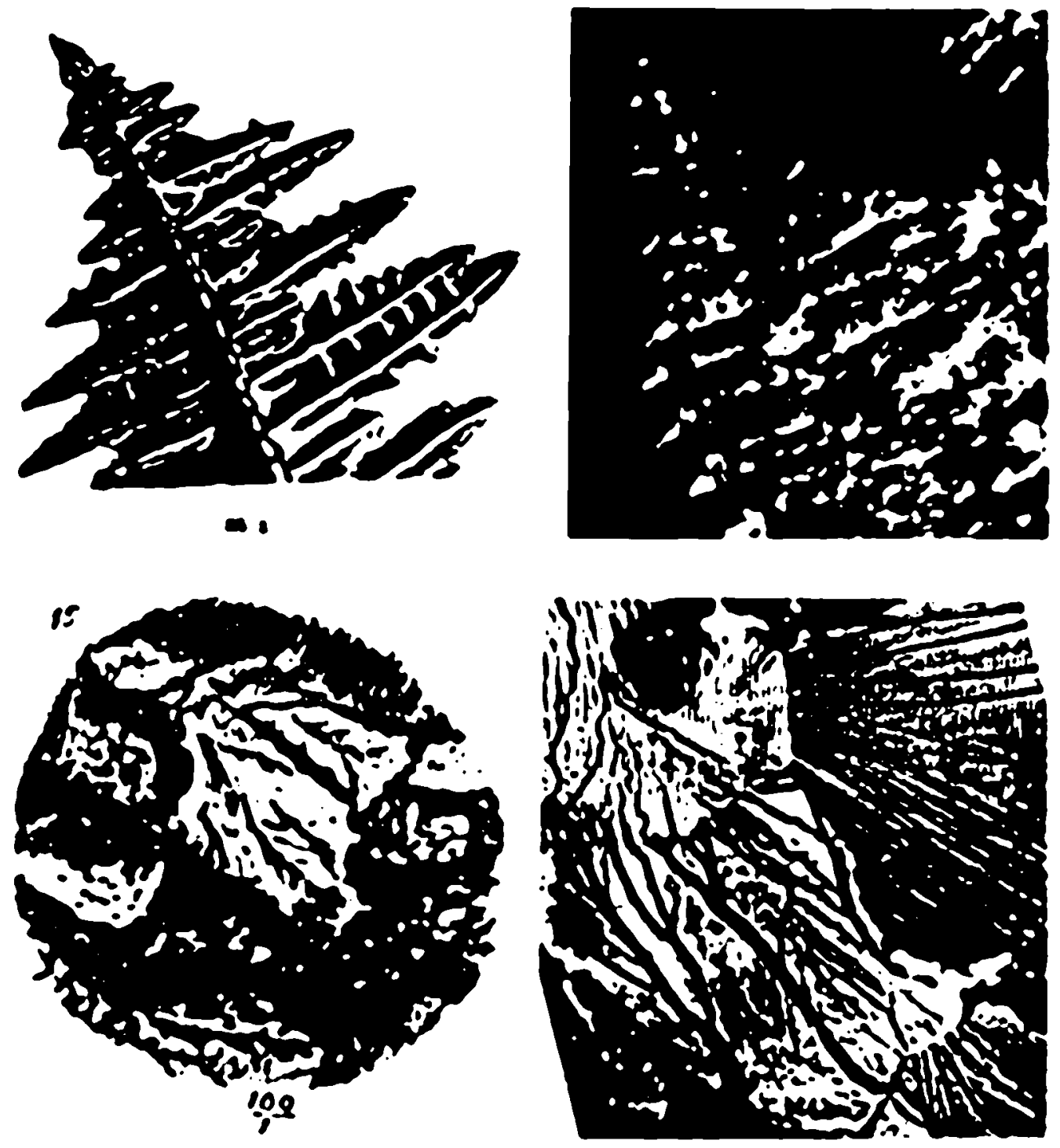

Pig. 5

FIg. 6
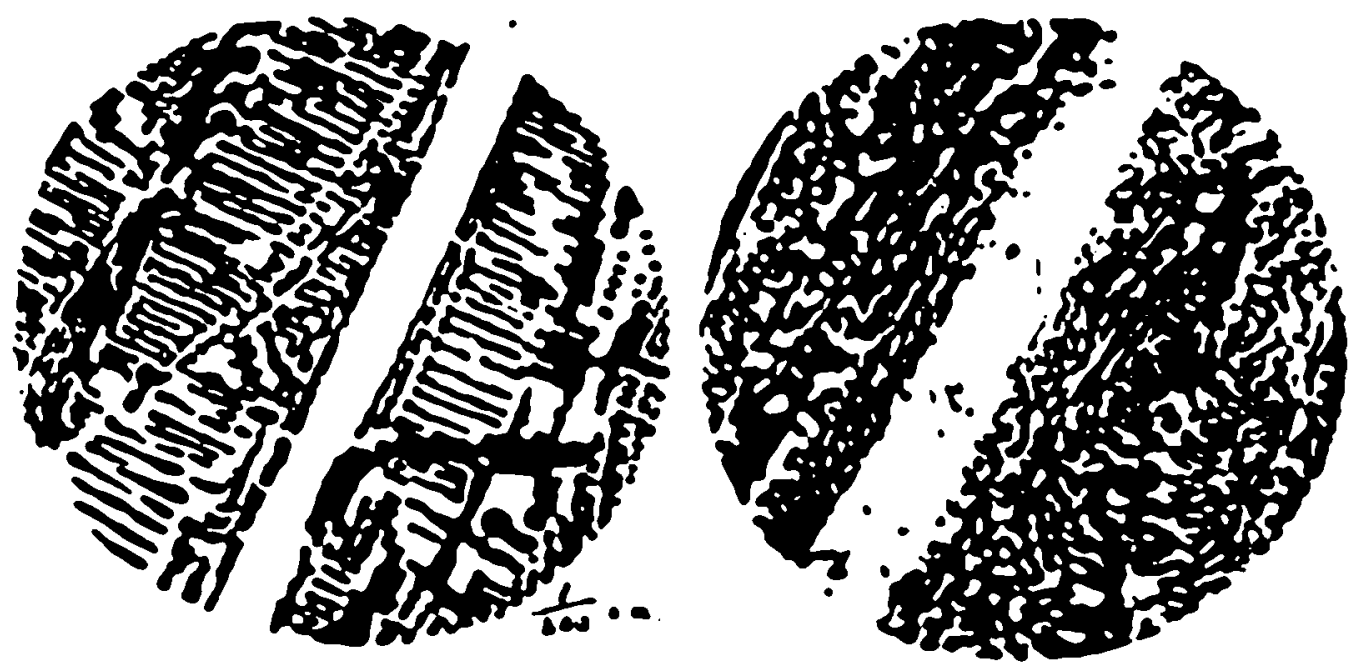
The research results and publicatlons of Martens - which cannot be reviewed within the scope of this paper - recelved considerable interest by his colleagues, so that Osmond termed the "martensitic" structure of steel after him (8). Although Adolf Martens published no own studies connected directly with the microstructural constituent of stecl which bears his name, attention should be drawn to the microstructural drawing by Martens. shown in Pigure 8. This drawing. which can be found in one of his publications (5). shows an impressive similarity to an essential feature of "martensite". namely the inhomogeneous shear pattern of internally slipped martensite plates, see Pigure 11.
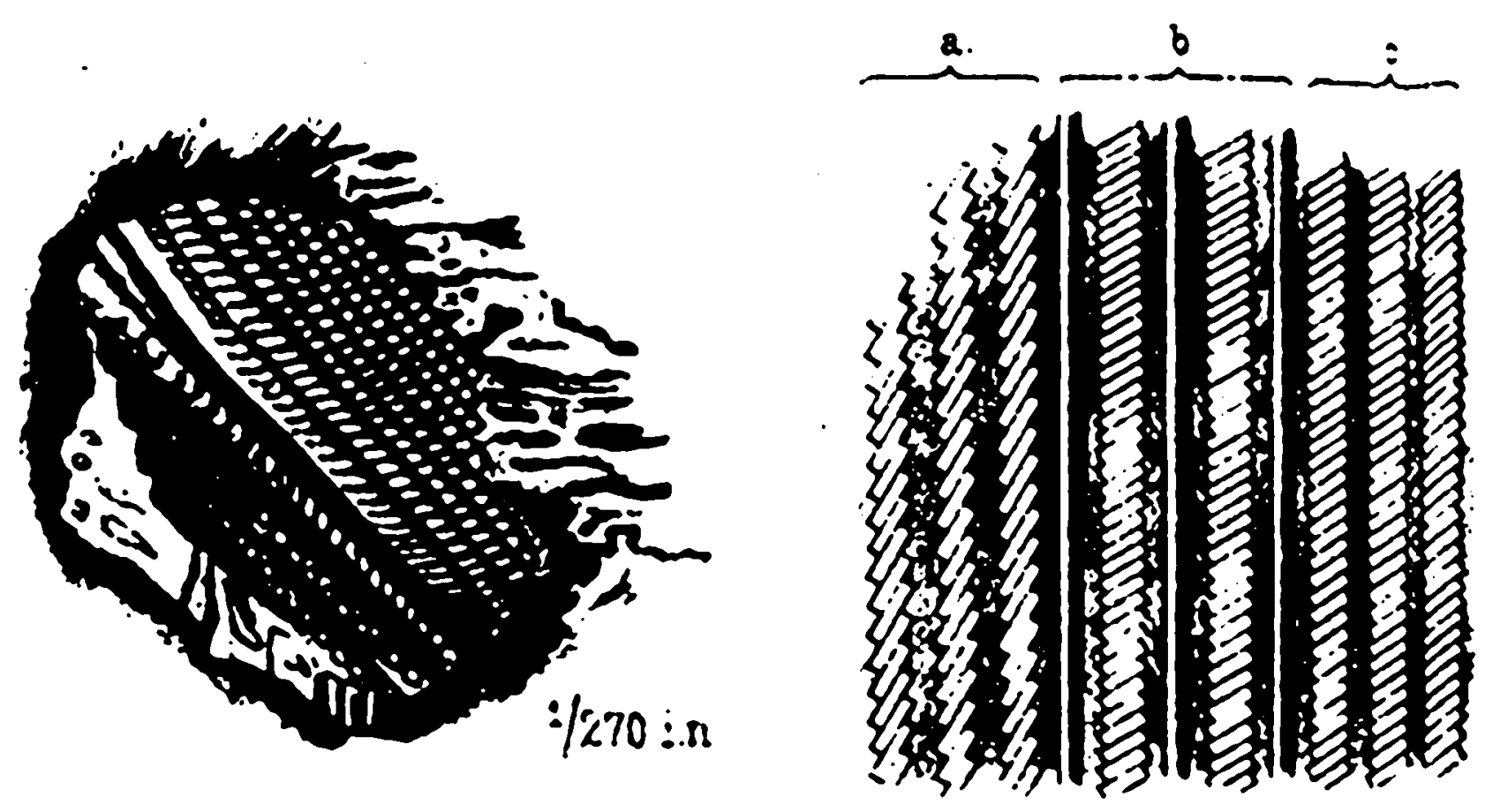

Fig. 8: Microstructural drawings by Adolf Martens

\section{Research on martensite today}

Nowadays the term "martensite" is used in a wide context to apply to the products of transformations taking place in crystalline solids by coordinated displacements of atoms or molecules over distances smaller than interatomlc distances in the parent phase. Martensitlc transformations have been observed In all classes of materials - metals, ceramics, polymers - as well as in blological structures, as lilustrated briefly in the following.

\subsection{Metals}

Historically. research on metals, mainly on steels, has led to the development of the phenomenological crystallography theory of the martensitic transformation. According to this theory there are three phenomenological steps describing the total transformation (9): 
(1) The Bain distortion: E.C. Bain suggested in 1924 (10) that the austenite(parent phase)-martensite transformation could be explained by a diffusionless homogeneous upsetting of the parent fcc lattlce into the required bcc (or bct) lattlce, involving minimal atomlc displacements, as shown schematlcally in Pigure 9. It was subsequently just if led mathematically that the particular correspondence between lattlces envisioned by Bain involves the smallest principal strains.

(ii) Inhorogeneous shear: In confunction with the bain distortion, a lattlce invariant deformation, such as slip, twinning or faulting occurs. This secondary deformation provides the Invariant plane condition at the macroscoplc scale and malntains a semicoherent glissile interface between the martensite and parent phase.

(111) The third step Involved in the phenomenologlcal crystallography theory of the martensitic transformation 18 a rigid body rotation.

The combined effect of the three operations (1), (11), (111) is equivalent to the experimentally observed shape deformation. There is no time sequence implied as to which occurs when.

In addition to the geometric models, dislocation theorles have been recently developed (11). According to these theorles, martensitic transformations are definod as a subject of diffusionless/ displaclve solid-state transformations in whlch the strain energy arising trom a shear-dominant lattice distortion controls the kinetics and product morphology during transformatlon. The dislocation description allows the prediction of numerous interfacial propertles, including the interfacial stress fleld, energy. stability and Interfacial mobllity. Application of the dislocation-based approach to the mechanism and kinetics of martensitic nucleation and growth has led to a reasonably quantitative explanation of the essential features of martensitic transformations.

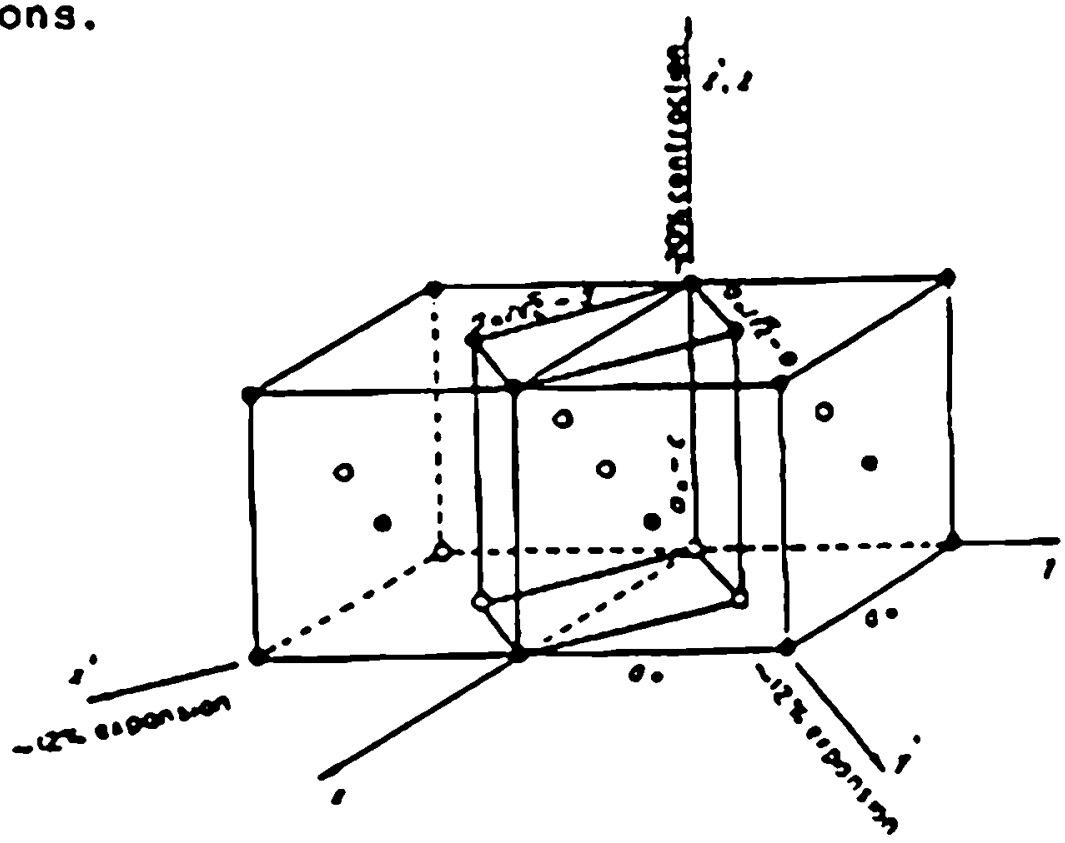

ig. 9: Bain distortion in iron alloys 


\subsection{Ceramics}

Displacive transformations involving large changes in volume or coordination number occur in ceramics as well as in inorganic compounds and minerals (12), see Table 1 .

\author{
Ceramics \\ Boron nitride: BN \\ Carton: C \\ Zirconia: $2 \mathrm{rO}_{2}$ \\ Inorganic Compounds \\ Alkall and ammonium halides: \\ Nitrates: $\mathrm{RbNO}_{3}$ \\ Sulphides: $\mathrm{MnS}_{3}, \mathrm{TINO}_{3}, \mathrm{AgNO}_{3}$ \\ 2ns \\ Bas \\ Minerals \\ Pyroxene chain silicates: \\ Enstatite ( $\mathrm{HigSO}_{3}$ ) \\ hollastonite (CaSiOz) \\ Silica: \\ Ferrosilite $\left(\mathrm{FeSiO}_{3}\right)$ \\ Quartz \\ Tridymite \\ Cristoballte
}

$$
\begin{aligned}
& \text { (wurtzite-type }=\text { graphite-type) } \\
& \text { (wurtzite-type = graphite) } \\
& \text { (tetragonal = monoclinic) }
\end{aligned}
$$

(NaCl-cubic $=\mathrm{CsCl}$-cubic)

( $\mathrm{NaCl}-\mathrm{cublC} \rightleftharpoons$ rthombohedral $\rightleftharpoons$

CsCl-cublc

(orthortambic =rhombohedral)

( $z$ inc blende-type $=\mathrm{NaCl}-\mathrm{cublc}$ )

(wurtzite-type $\rightleftharpoons \mathrm{NaCl}$-cubic)

(zinc blende-type $\Rightarrow$ wurtzite-type)

( $\mathrm{NaCl}$-type $\rightleftharpoons \mathrm{CsCl}$-type)

(orthortombic $\rightleftharpoons$ monoclinic)

(monoclinic $\rightleftharpoons$ triclinic)

(orthortambic $\Rightarrow$ monocl inic)

(trigonal $\rightleftharpoons$ hexagonal)

(hexagonal, wurtzite-related)

relabic $\underset{\text { retragonal. }}{\mathrm{z}}$ inc blende-

The typical martensite appearance known from metals is likewise found for certain types of ceramics. For example, a characteristic martensitic microstructure develops by cooling a $2 \mathrm{rO}_{2}-\mathrm{Sc}_{2} \mathrm{O}_{3}$ alloy from the high-temperature cubic(c) phase region to Ehe $\beta$-phase region (13), see Figure 10. The microstructure of the B-phase usually has a "herring-bone" structure, likely to be a favourable one for minimizing the strain energy and interfacial energy associated with the $c-\beta$ transformation.

In bulk single crystals of zirconia $\left(2 \mathrm{rO}_{2}\right)$, the tetragonal to monoclinic transformation was experimentally and theoretically proven to be martensitic.

By exploiting the martensitic phase transformation of discrete $z$ irconia particles dispersed within ceramic matrices, the mechanical properties of brittle ceramics can be improved. The toughening originates from the crack shlelding associated with the volume and shape change of the martensitic transformation and reduces the stress intensity at the crack tip. This type of energy dissipation is analogous to that associated with crack tip plastlcity in ductile metals. Three basically different classes of $2 \mathrm{rO}_{2}$-toughened ceramics have been identified (14): 
(1) Partially-stablilized $2 \mathrm{rO}_{2}$ (8Sz), In which tetragonal $2 \mathrm{rO}_{2}$ partlcles are coherently preclpltated wlthin a cubic stablitied $\mathrm{ZrO}_{2}$ matrix (precipitation-toughoned ceramlcs)

(1) Tetragonal $\mathrm{ZrO}_{2}$ polycryatalo (T2P) whlch consist predomlnantly of fine tetragonal $2 \mathrm{rO}_{2}$ matrlx gralns. These ceramlcs represent a very strong class of coramlc materials (bend strength $>2000 \mathrm{MPal}$

(111) $2 \mathrm{rO}_{2}$-toughened ceramics (2TC), where tetragonal or monocllnle $2 \mathrm{rO}_{2}$ particles are dispersed In ceramlc materials such as $\mathrm{Al}_{2} \mathrm{O}_{3}$. mullite $\left(3 \mathrm{Al}_{2} \mathrm{O}_{3} \cdot 25 \mathrm{IO}_{2}\right.$. splnel $\left(\mathrm{Mg} \mathrm{Al} \mathrm{O}_{4}\right)$, etc. (disperlon-toughened ceramlcs).

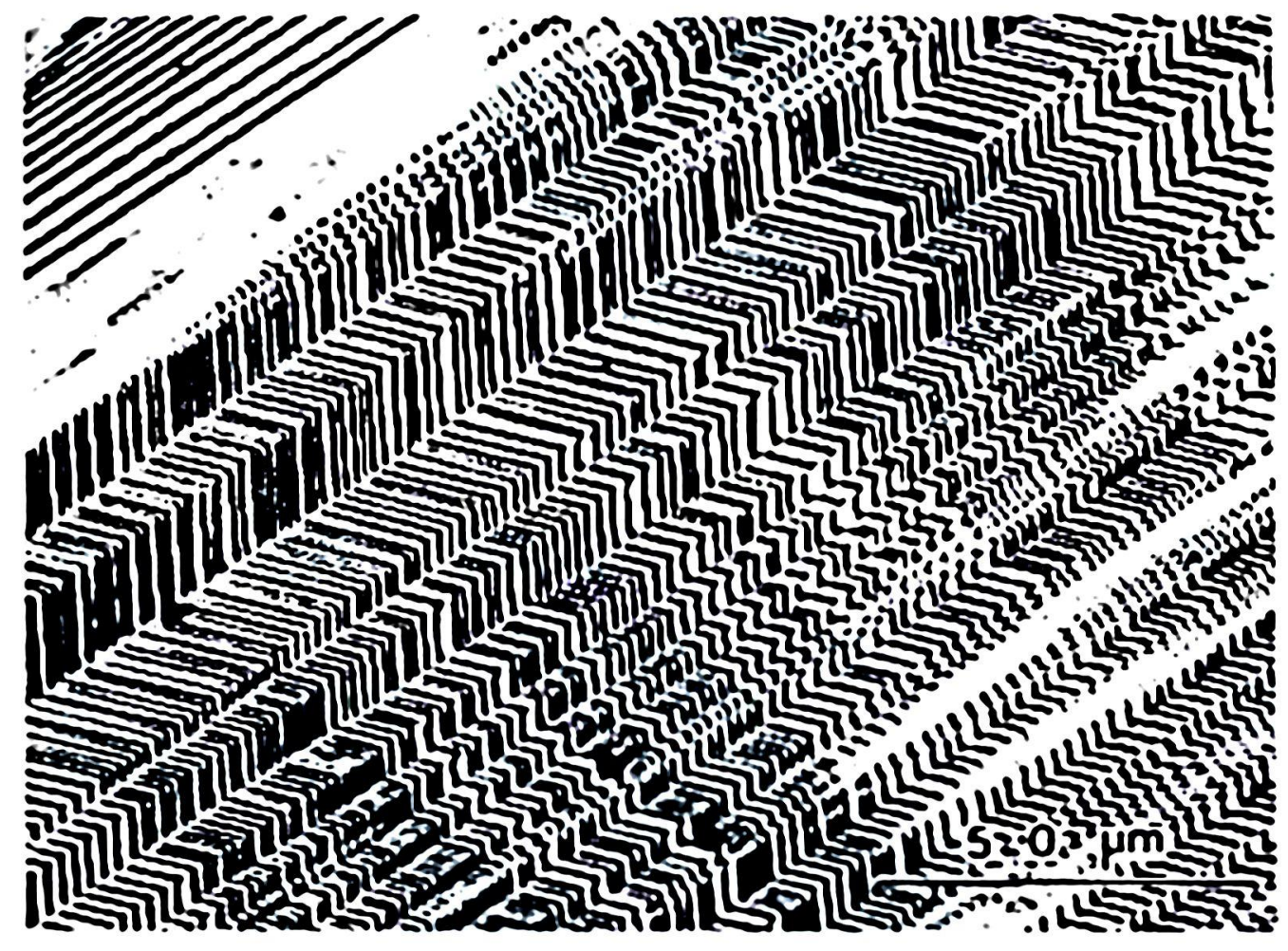

Fig. 10: Herring-bone structure ol $2 \mathrm{rO}_{2}-\mathrm{Sc}_{2} \mathrm{O}_{3}(\beta$-phase)

\subsection{Polymers}

In order to analyze the posalbllltles of polymorphism in polymers, a survey of the shapo changes that can be associated wlth diffusionless transformationa la glven ln figure 11 (15).

I. Lattlce variant deformation can be composed of

(1) shear without change In volume

(11) volume change wl thout shoar.

I. Lattice Invarlant deformation $1 \mathrm{a}$ always required, if the transformation takes place in the Interlor of the matrix phase

(iii) plastic shear by 8 llp or ewinning

(Iv) elastic (not shown in Plgure 11 ). 


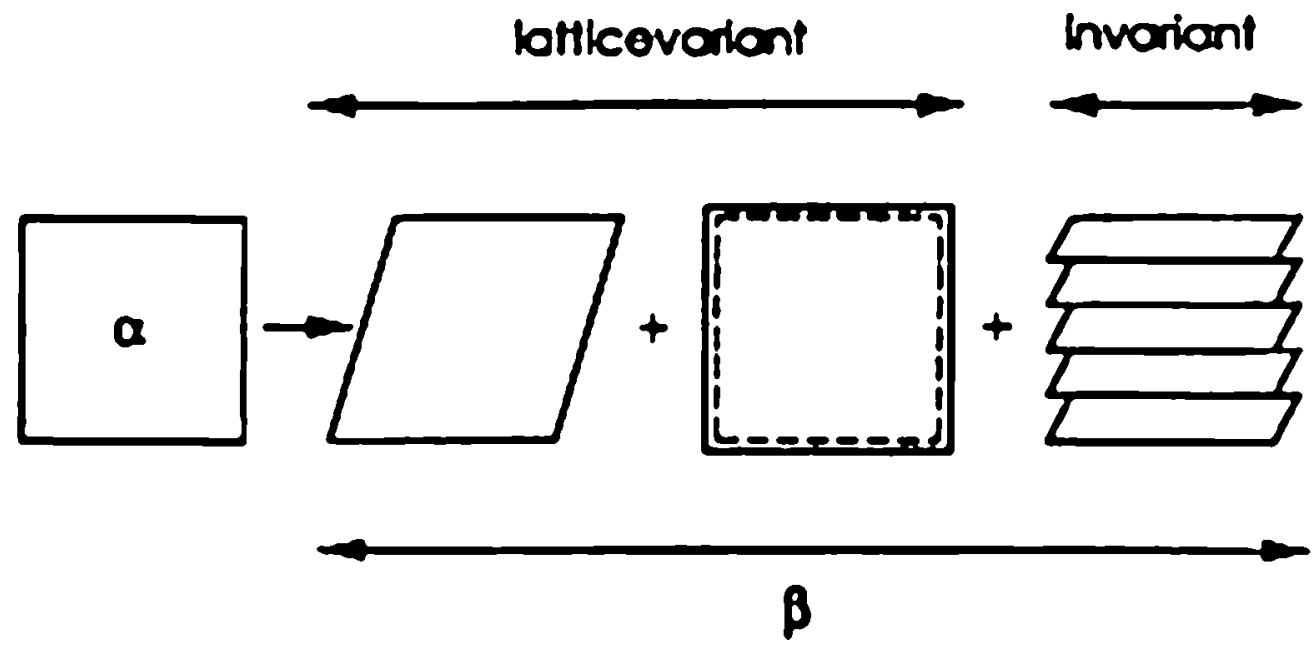

Plg. 11. Shape cbanges of diffusionlose transformations

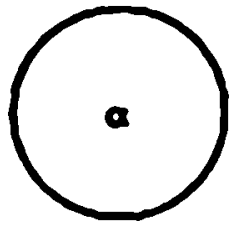

Original

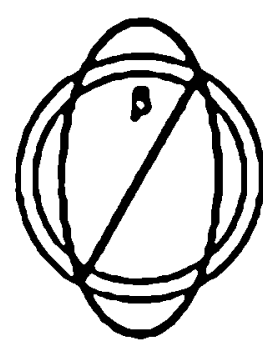

shear plus volume chonge (steols)

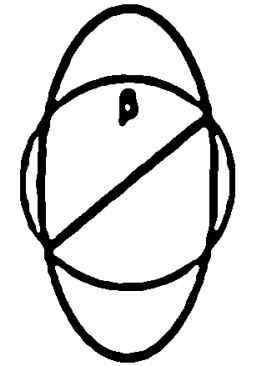

Pure shoor (shopomemory olors)

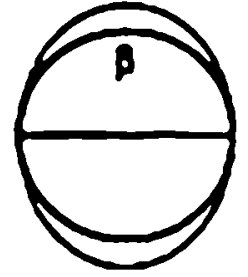

$\sin \theta$ or-freo volume chonge (PIFE)

Plg. 12: Posslblilties for lattlco-varlant deformations

The prlnclpal cases of lattlce varlant shear are show in Plgure 12. An example for the general caso in wich shear and volue change occur simultaneously are lron-base alloys. The shapemerory alloys based on the CsCl-structuro (0.9. Cu2a. Niti) c000 closest to the case of pure shear vithout volune change. The poIyaer PrTe is an example for the case in wich the volume chan90s, but no shear can occur. Exporlaents have shom that the PTFE eransforses by a special eype of diffustoniess transformation that takes place by a abear-free lattlce varlant volume cbange and latelce Invarlant elastle straln (15).

Fron studles on other organic inglo crystals lt was concluded that a crltical resolved shear straln crlterton determines which poselblo deformation or transformation mode occurs on application of unldirectlonal stress. The magnltudo of the shear strain must be amall ince the conflguration of that fold geometry restricts tho operation of largo deformation modos. The transformation or doformation mechanism favoured 1s the one wlth the simplest shuflles or displacements of molecular chalns. Por example. in single cryetal fllms of polyethylene under olrectlonal tenslle stress. the crystallography of the observod deforantion modes indlcated that twinaing. repeated twinning and allp occured in connection with in orthorhable to monoclinte transforation (12). 


\subsection{Blologlcal martensitic trangformations}

Recent research indicates that martensitlc trangformations are also well represented in biology (11). Pigure 13 shows the example of tall-sheath contraction in the T4 bacteriophage, a virus which infects E. Coli bacterla. The virus consists of a DNAfliled lcosahedral head or capsid attached to a tall assembly composed of a riqfd tail-core, a cylindrical tall-sheath, and a baseplate assembly with $s i x$ long and short tall fibers. The tallsheath is a metastable two-dimensional protein crystal closed to form a cylinder. When the tall flbers attach to the approprlate bacterlal membrane, they distort the baseplate which, in turn. triggers a straln-induced single-interface martensitic transformation in the crystalline tail-sheath. The transformation shape strain produces a substantial contraction which drives the rigid tail-core through the bacterlal membrane, injecting the virus DNA into the bacterlum.

Figure 14 deplcts a coherency dislocation model of the martensitic interface trangforming the protein crystal between the structures corresponding to the extended and contracted states. The hellcal nature of the cyllndrical crystal provides a built-in pole mechanlsm whereby only a fixed number of dislocations is necessary to spiral up the close-packed rows and completely transform the crystal. The transformation shape strain involves a shear greater than 1008, which not only shortens the sheath but also provides a large twist about the cyllnder axis, thus helping the tail-core to "bore" through the bacterial cell wall.
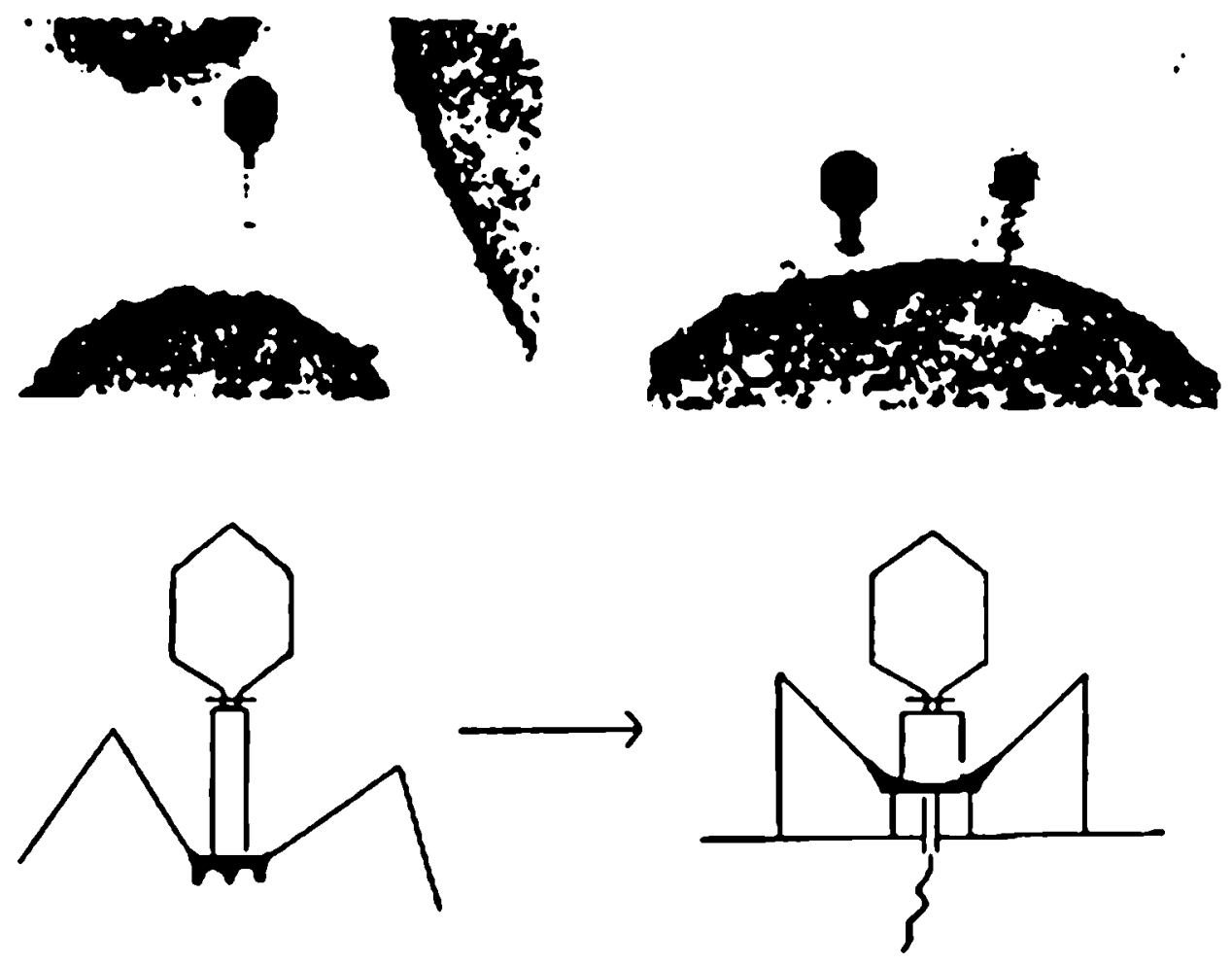

Fig. 13: aacterial virus tail-sheath contraction 


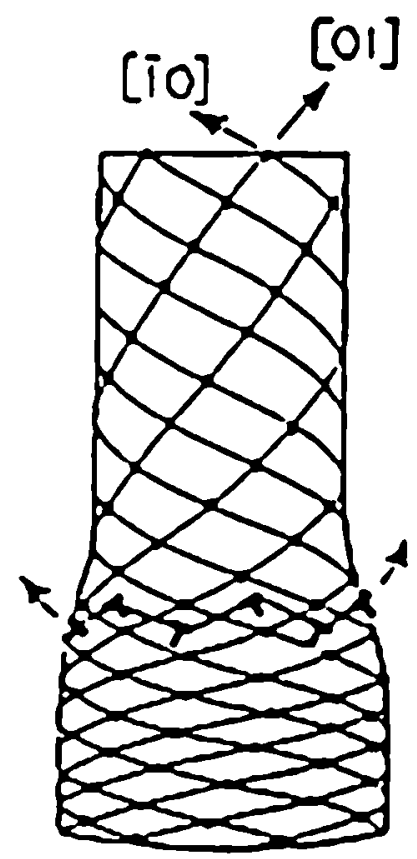

Flg. 14: Virus contraction by martengltic transformation

5. Pinal remark

The examples from the areas of metals, ceramics, polymers and biology indicate the impact of martengltle transformations not only for materials science and englncerling but also for the control of motion and shape in living things. The Pederal Institute for Materials Research and Testing (BMM) Berlin is proud that the name of Adolf Martens - One of the fathers of BAM - is connected with this important field of technology and science. This paper is dedicated to his memory.

\section{References}

(1) C.S. Smith: A History of Metallography. The Oniversity of Chicago Press, Chicago, I11.(1960).

(2) E. Heyn: Stahl und Elsen. 34(1914) 1393.

(3) 0. Herner: MaterialprJfung. $6(1964) 249$.

(4) A. Martens: Stahl und Elsen. $2(1882) 94$.

(5) A. Martens: VDI-Zeitschrift. 22(1878) 11, 205, 483.

(6) A. Martens: VDI-zeltschrlft. 24(1887) 397.

(7) A. Martens: Stahl und Filsen 7(1887) 235.

(8) M.P. Osmond: Arts Chimiques. 94(2895) 480.

(9) M.B. Bever (Editor): Encyclopedia of Materlals Science and Englneering. Oxford: Pergamon Press 1986, P. 2736 ff.

(10) E.C. Bain: Trans.AIME. 70(1924) 25.

(11) G.B. Olson. M. Cohen: Dislocation Theory of Martensitic Transformation, in: Dislocatlong in Sollds (F.R.N. Nabarro, Editor), Amsterdam: North Holland, 1986, p. 297 ff.

(12) W.M. Kriven: Lattice - deformat lonal transformations in non-metals. Int. Summer Course on Martengltlc Trangformations, Leuven, August 1982.

(13) T. Sakuma, H. Suto: J. of Mats. Sclence, 21 (1986) 4359.

(14) N. Claussen: 2 . Werkstofftechnik. $13(1982) 138$.

(15) E. Hornbogen: Progr. In Collold and Polymer Science. $64(1978) 125$. 